Article

\title{
Consuming Desire in Under the Skin
}

\author{
Yael Maurer ${ }^{+}$ \\ Independent Scholar, Tel Aviv 6997801, Israel; yael.maurer@gmail.com \\ + Formerly at The English and American Studies Department, Tel Aviv University, Tel Aviv 6997801, Israel \\ (2010-2019).
}

Received: 5 April 2020; Accepted: 29 April 2020; Published: 4 May 2020

\begin{abstract}
Jonathan Glazer's 2013 film Under the Skin is a Gothicized science fictional narrative about sexuality, alterity and the limits of humanity. The film's protagonist, an alien female, passing for an attractive human, seduces unwary Scottish males, leading them to a slimy, underwater/womblike confinement where their bodies dissolve and nothing but floating skins remain. In this paper, I look at the film's engagement with the notions of consumption, the alien as devourer trope, and the nature of the 'other', comparing this filmic depiction with Michael Faber's novel on which the film is based. I examine the film's reinvention of Faber's novel as a more open-ended allegory of the human condition as always already 'other'. In Faber's novel, the alien female seduces and captures the men who are consumed and devoured by an alien race, thus providing a reversal of the human species' treatment of animals as mere food. Glazer's film, however, chooses to remain ambiguous about the alien female's 'nature' to the very end. Thus, the film remains a more open-ended meditation about alterity, the destructive potential of sexuality, and the fear of consumption which lies at the heart of the Gothic's interrogation of porous boundaries.
\end{abstract}

Keywords: Gothic; science fiction; alien; gender; kin; Scarlett Johansson; Michael Faber; Jonathan Glazer

Jonathan Glazer's 2013 film Under the Skin (London BFI, Film 4) is a generic hybrid. The film's protagonist, an alien female, travels across Scotland's gloomy landscape, seducing unsuspecting male hitchhikers and leading them to their demise, in what seems like an underwater 'tomb'. Glazer blends documentary footage with a Gothicized science fictional narrative, thus creating a film about sexuality, alterity and the limits of humanity. Glazer's film engages with alienness, abjection, national and personal 'otherness' and male-female sexual dynamics, employing the science fiction/horror narrative as a vehicle for querying the very idea of the 'human' as an observable and knowable category. By presenting the viewers with an open-ended and enigmatic tale of an alien being in female form and 'her' uncanny encounters with the male species on Earth, ending with an exposure of what seemingly lies under the skin of the female alien, Glazer's film enacts the troubling notion of the porous and permeable boundaries between what is deemed 'human' and what is seen as 'other'.

The troubled male-female relationships depicted in the film mirror the science fictional human-alien interactions. The film presents sexual dynamics as an 'alien' encounter and offers us an 'alien' view of desire. The alien female's purpose in luring her male victims is revealed in the novel on which the film in based: the humans are hunted by the alien female as 'meat' to be consumed by her alien race. Glazer's film only hints at the alien's purpose, leaving the viewers with uncanny images of the male body's dissolution in a watery environment.

Sexual desire, death, and consumption are presented in the film as intimately linked. The confusion of boundaries between the 'human' and the 'alien', a major trope in science fictional narratives, is presented in Glazer's film via the dynamics of sexual desire. The female alien's quest for selfhood in an (alien) male world is clearly also a metaphor for the vexed relationship between the sexes. This becomes even more apparent in Michael Faber's novel, the basis for Glazer's filmic adaptation. 
In the novel, the alien voice is heard and 'her' motivations are presented to the reader. While Glazer's film remains more ambiguous than the novel, it still presents viewers with scenes which enact the troubling nature of male-female relations, the 'alien' nature of our humanity, and the role of consumption in its many forms in the interaction between human, alien, and animal as different forms of alterity.

What lies 'under the skin'? What are the implications of this discovery? Both novel and film evoke the notion of kinship, querying what lies under the skin. The film remains ambiguous about the ability to find out the answer to this question, presenting us instead with an allegorical tale about the human condition as always already 'other'. The film's protagonist, an alien female, passing for an attractive human, seduces unwary Scottish males, leading them to a slimy, underwater/womblike confinement where their bodies dissolve and nothing but floating skins remain. The men are led 'home' and back to the 'womb' which becomes a slimy/watery tomb. The uncanny effect of the seduction/disintegration scenes is offset by the use of candid camera shots employing non-actors as the unsuspecting Scottish men who are accosted by the American actress Scarlett Johansson, in the role of the female alien, donning a black wig which makes her unrecognizable to the unsuspecting men she encounters. Daniel Landin, the film's cinematographer, explains Glazer's motivation for using the 'candid camera' method: "We wanted to be very discreet about getting in, shooting and leaving" (Stasukevich 2014, p. 45). The film utilizes the documentary mode thus further stressing its status as a generic hybrid.

In this paper, I look at the film's engagement with the notions of consumption, the alien as devourer trope, and the nature of the 'other', comparing this filmic depiction with Michael Faber's novel on which the film is based. Rethinking Deuleuze and Guattari's famous notion of the 'body without organs', I look at the film's depiction of the body as a mere container to be emptied out. Donna Haraway's notions of kinship across species, Barbara Creed's evocation of the monstrous feminine trope, and Julia Kristeva's evocation of the abject are employed as avenues of exploration of the novel and filmic depictions of alterity. Employing these theoretical paradigms, I examine the film's reinvention of Faber's novel as a more open-ended allegory about the human condition as always already other. Faber's novel offers a more detailed depiction of the female alien's motivation and her inner world. The novel's plot unfolds to reveal the nature of the alien race and their purpose on Earth: killing and then processing 'vodsels' (the alien name for humans), in order to prepare them for consumption by the alien species. Thus, the novel metaphorically evokes the human-animal relationship of domination and mastery and turns it on its head, making the aliens 'human' and the 'humans' their unwitting prey.

Glazer's filmic adaptation of the novel, however, offers a radical departure from this narrative coherence. The novel is mostly focalized through the alien female's consciousness, interspersed with her victims' uncomprehending and non-empathic view of her and of women in general. In contrast, Glazer's film chooses to remain ambiguous to the very end. The viewers are left with an open-ended enigma about the nature of alienness; the female alien is set on fire in the forest by a male logger who, after his attempted rape of the female, is appalled when her true 'nature' is revealed as she peels off her seemingly human skin. However, this horror/fairytale like ending only reinforces the very ambiguity at the heart of the film. The alien female's journey in Scotland's gloomy moors, which are a strange and almost other-worldly locale, teaches her the fraught nature of femininity in a male dominated world. The grim Scottish locale seems best suited for an exploration of alienness, desire, and death.

Alterity seems to be the very condition explored by the film, and it thus can be read as an allegory of the ways not everyone is 'the same under the skin'. This cliché is subverted in Faber's novel. Unlike Glazer's film, where the alien remains nameless and is only identified in the film's credits as "the Female", Faber gives the alien female a name, Isserley, and a voice: she is the focalizer for significant portions of the novel, undercut by her male hitchhikers' inner monologues. Isserley's role is to seduce the males, offering them a ride and luring them to her van where she anesthetizes them with a built-in device inserted in the passenger's seat. Once they are rendered helpless, Isserley 
drives back to the farm, where the captured males undergo the processing undergone by farm animals, to finally be butchered and made into pieces of meat for the rich inhabitants of her alien home planet. Consumption, then, is a key concept in Faber's novel. The alien species hunt and process 'vodsels' as a precious commodity to feed their 'elite'. The horrific nature of this capitalist practice is described in gruesome detail in the novel, providing the readers with a not-too-thinly-veiled allegory of the ways 'we' treat animals.

However, by presenting the narrative from the 'alien' point of view, Faber complicates the boundaries we erect between what we deem as 'human', 'animal' and 'alien/other'. Isserley's role is to capture the 'vodsels' and, in order to perform her job, she has to deny their 'humanity', viewing them as mere beasts who possess no language, much like we view the animals we capture, process, kill and eat.

Faber's novel is then both an allegory of the (in)human treatment of animals at the hands of humans and a comment on current society's treatment of its 'others', animals and women alike. Isserley is the alien who shows us our own distorted view in a cultural mirror. Faber's novel offers a scathing critique of male-female dynamics in a patriarchal society which seems to remain the same whether you are an animal, an 'alien' or a female. Isserley's dealings with the alien males on the farm demonstrate how the patriarchal structure remains intact in this alternate alien society. There is no blurring of gender roles, or any form of gender equality. Rather, Faber presents mirror images of human society and its treatment of its 'weaker' members, namely women and animals, as analogous in both 'worlds' of the novel. This mirroring effect both alerts the reader to the innate horror of man's inhumane treatment of his fellow animals and to the innate injustice of a gendered system where women are also perceived as 'meat' to be symbolically consumed by men.

In a key scene in the novel, Isserley comments on the other male aliens' seeming sympathy for her upon her arrival at the farm where the alien species process the 'vodsels' and prepare them for consumption by the alien race: "[S]he was a poor little thing, she must be so upset at how she had been ... messed about with, yes, they understood all about that, ... but she was brave, yes, she was a plucky girl, and they would treat her as if there were nothing odd or ugly about her at all, for she and they were all the same under the skin, weren't they?" (Faber 2001, p. 152). Isserley's ironic tone belies the clichéd expression rendering it 'alien': if the alien race who view humans as 'vodsels' and hunt them down are mirror images of humanity's failure to see the 'other', then this bitter comment on alterity, both as a 'woman' and as an 'alienated' other resonates in Faber's novel as well as in Glazer's more enigmatic filmic adaptation.

The choice of the Scottish locale is also indicative of the ways Glazer imagines 'alienness' as an inherent feature of a 'national' landscape. In one of the key scenes in the first part of the film, the alien female encounters a surfer on the beach. He too, is a stranger in a strange land. To her question about where he is from, he answers that he left the Czech Republic and came to Scotland because "it's nowhere".

Foucault's notion of heterotopia encapsulates this concept of a 'real' place that is in effect, 'nowhere'. As Foucault elucidates in "Of Other Spaces: Utopias and Heterotopias": "There are ... real places ... which are something like counter-sites, a kind of effectively enacted utopia. Places of this kind are outside of all places even though it may be possible to indicate their location in reality. Because these places are absolutely different from all the sites that they reflect and speak about, I shall call them, by way of contrast to utopias, heterotopias" (Foucault 1984). Scotland's wild landscapes and gloomy city scenes form a heterotopic space in the Foucauldian sense. Scotland thus becomes, in both novel and film, a reflection of the alien female's difference. If Scotland is a heterotopic space in the Foucauldian sense, then the alien female is like 'Scotland': She comes from 'nowhere' (an alien place we know nothing of), to 'nowhere' (Scotland as the ultimate figure of difference).

The scene on the beach culminates with the drowning of a young couple. Their baby is left behind on the beach, ignored by the female. The female's indifference to the deaths of the family on the beach and her subsequent murder of the surfer, show her 'alienness' as a cruel lack of 'humanity'. Her total 
disregard for human life is offset by the view of the indifferent ocean which swallows its victims alive. Likened to an indifferently cruel Nature, the alien female also absorbs her victims in what seems to be a watery element which dissolves and annihilates them. In Faber's novel, the Scottish background also serves to highlight elements of monstrosity and (national) and gendered alterity: "Two male vodsels dressed in mauve tights, ruched blouses and bizarre green hats like stuffed Loch Ness Monster toys were standing next to a hole in the ground, out of which loose earth was being jettisoned like little puffs of brown breath" (Faber 2001, p. 144). The evocation of the Loch Ness Monster further enhances the idea of Scotland as a 'monstrous', alien, heterotopic space. In a novel which rethinks the notion of monstrosity, this ridiculed depiction of the Scottish males complicates the view of monstrosity and otherness. This image is compounded when Isserley fails to understand the "outlandish accent stranger still than Glaswegian" (ibid., p. 145) spoken by the 'vodsels'. In a similar manner, Glazer's film utilizes the unintelligible Scottish accent of the male hitchhikers picked up by the alien female, as a way of compounding the confusion of both character and viewers. The seduction/dissolution scenes are a wordless 'dance' of desire and death; the female and the males she seduces perform this ritual which remains an ambiguous image of the relationship between the sexes, the representation of consumption as a cultural trope, and the close links between desire and death. The gendered role reversals in the seduction scenes also relate to the film and novel's evocation of the female body as an object of male desire, the male body as an object of the female's lethal gaze, and the commodified nature of male-female interactions, as well as the human-animal relationships which Faber's novel makes explicit. By making the alien female the 'hunter' and the unwitting men her 'prey', Glazer alerts the viewers to the ways we construct gendered roles, reflects the male fear of female sexuality as a devouring force, and hints at the relations between humans and animals, made explicit in Faber's novel. The logger who sets the alien female on fire at the end of the film, becomes an image of the ultimate hunter. He is both a sign of male sexual aggression, an image of brutal force directed at an 'alien' threat, and a coded representation of "Man" as the archetypal hunter of weaker creatures, the destroyer of 'otherness' in female (alien) form.

\section{Under the Slime: Dissolving Bodies and Sexual Angst}

Glazer's film, unlike Faber's novel, maintains an ambiguity as to what exactly has happened to the unlucky hitchhikers who accept the alien's offer of a 'ride'. The almost abstract depiction of a dark surface where the men follow the alluring female as she teasingly disrobes only to be mysteriously 'dissolved' remains the most deeply disturbing image in a film replete with eerily menacing scenes.

As Lorna Piatti-Farnell notes in Consuming Gothic: Food and Horror in Film, the film enacts the "strange and estranging" process of "osmosis and incorporation" where the "human body literally melts away into the mass of the slimy substance" (Piatti-Farnell 2017, p. 75). Drawing on Jean Paul Sartre's evocation in Being and Nothingness of the "slimy" substance as representing a disturbing in-between state: between liquid and solid, sticking to the body, and "leeching" on it (ibid., p. 73), Piatti-Farnell relates to the film's use of the "slimy" element as a horror-inducing mechanism.

Sartre relates to the horror of the slimy substance in Gothic terms. The slimy substance evokes horror because it "highlights the boundaries of our bodies and the possibility of un-recognition of those boundaries" (p. 73). Sartre's image of this uncanny "blending", where the body's boundaries become "porous" (p. 75), recalls the maternal womb and the cultural idea of the cocoon, which is also part of the horror imaginary. Sartre speaks of the "haunting memory of metamorphosis" (p. 75) and this metamorphosis is seen in the film as an uncanny return to a pre-birth state. As Piatti-Farnell elucidates, "the notion of metamorphoses is represented in Under the Skin as haunted not only in terms of its own ancestral memory but also on a disrupted future based on the Gothicised notion of change" (p. 75). In other words, in this Gothic/science fictional narrative, the scenes of the porous male body blending into a kind of maternal abyss are evocative both as a cultural unconscious memory and as a psychological depiction of the horror of the return to the womb as a tomb; fear of the monstrous 
maternal is given a very uncanny visual representation in the film as the male bodies return to what seems to be a 'primal' or almost embryo-like state, before birth.

Kristeva's famous notion of the "abject" seems to permeate this representation of the body as a locus of horror. As Kristeva notes in The Powers of Horror: An Essay on Abjection: "The body's inside ... shows up in order to compensate for the collapse of the border between inside and outside. It is as if the skin, a fragile container, no longer guaranteed the integrity of one's 'own and clean self' but, scraped or transparent, invisible or taut, gave way before the dejection of its contents" (Kristeva 1982, p. 53). Kristeva links this notion to the maternal: "The abjection ... flows from within suddenly become the sole 'object' of sexual desire-a true 'abject' where man, frightened, crosses over the horrors of maternal bowels and, in an immersion that enables him to avoid coming face to face with another, spares himself the risk of castration." (ibid., p. 53) However, as Kristeva notes, "at the same time that immersion gives him the full power of possessing, if not being, the bad object that inhabits the maternal body" (p. 54). In other words, the 'immersion' in the maternal element, as seen in the seduction scenes in Under the Skin becomes a site of desire and death, the meeting point with the 'other' as feminine/maternal, or what Kristeva names the "desirable and terrifying, nourishing and murderous, fascinating and abject inside of the maternal body" (p. 54). In the figure of the alien female in Glazer's film, and Faber's novel, we find a representation of that very horror of what Kristeva names "the confrontation with the maternal" (p. 54).

The 'slimy' element in the film is also highly seductive. The males are seduced by the alien female and the slimy black substance is associated with her, and with male desire becoming deadly. As Piatti-Farnell explains: "Desire is somehow 'punished' by the dark matter as the slimy is presented, not only as a harbinger, but as an irresistible agent of death" (Piatti-Farnell 2017, p. 76). But this element is also water-like, invoking the womb and its "watery" environment. The men are aware of their own slow disintegration into the slimy/liquid matter. Thus, the "consumption relationship in Under the Skin [is] a reversal of the maternal connection, a fearful subversion of the mother-child narrative" (ibid., p. 77) and "the already disturbing system of sliminess" in the film is transformed into "a horror re-elaboration of maternal ingestion" (p. 77). Glazer's choice of the minimalistic black surface instead of a more explicit employment of the horror film conventions for showing a human being devoured by an alien monster (as seen most famously in films like Ridley Scott's Alien), allows for a more metaphorical depiction of the horror of ingestion. We are shown a 'stage' on which this drama of incorporation and dissolution takes place, but the viewers are left pondering the exact nature of this horrific experience undergone by the male hitchhikers who follow the seductive female.

The inscrutable scenes of absorption into the black slime/water element can also be read as a metaphor for the very inscrutability of Glazer's film. As Lucas Hilderbrand notes in "On the Matter of Blackness in Under the Skin",

At first it seems firm, like glass. Then it seems like tar, clinging to the men and drawing them down-though without the residue of stickiness. Seen from underneath, it seems like water. From above, it is opaque. From below, it is translucent, like a tinted window. It is inky yet leaves no stain. It is a blackness that at first absorbs (the human) and then glossily reflects (the alien). The fluidity of this black substance suggests that it is an unstable metaphor. Beyond human comprehension, it's a metaphor that only makes sense to the alien, who does not seem to notice its oddity. To reference yet another metaphor of blackness, this is like a black hole that absorbs all interpretations and meanings that we might project onto it. (Hilderbrand 2016)

According to this reading, the film's engagement with the alien 'other' is "beyond human comprehension". This is not the case in Faber's novel which still offers readers a way of engaging with 'otherness' as a mirror of our own all too human condition and explores the ways animals, humans, and 'aliens' become figures of difference. Unlike the film, Faber's novel then provides us with different perspectives: Isserley and the men she picks up are given a voice and the readers are given different points of view of the same narrative. Glazer's film remains more 'objective', providing the viewers 
with an enigmatic, visual tale, with very little dialogue, and retaining the ambiguity about the female alien to the very end, thus ensuring an open-ended narrative.

\section{Humans, Animals and the Gendered Divide}

Faber's novel interrogates the many ironies inherent in Isserley's position as an 'alien' (in our eyes), a hunter of 'vodsels' who are a stand-in for 'humans' and an explorer of Earth and its multiple species. Isserley who has no qualms about capturing 'vodsels also strongly identifies with the sheep she sees: "She liked sheep more than any other animal; they had an innocence and a serene intentness about them that was worlds away from the brutish cunning and manic excitability of, say, vodsels. Seen in poor light, they could almost be human children." (Faber 2001, p. 150). Isserley is also very careful not to contaminate Nature after bathing in the lake: "She hoped the shampoo wouldn't do any harm to the things that lived in the loch. A few drops of chemical soap into such a vast reservoir of natural purity wouldn't have much effect, surely?" (p. 287).

Returning to Donna Haraway's famous evocation of the confused boundaries between (wo)man, animal, and machine in the Cyborg Manifesto, we can see how Faber's novel enacts this kinship as a possibly redemptive option. As Haraway frames it, "the boundary between human and animal is thoroughly breached" (Haraway 2000, p. 293). This radical claim is also related to feminist culture: "[Many] branches of feminist culture affirm the pleasure of connection of human and other living creatures" (ibid., p. 293). Haraway relates to animal rights movements, claiming they are "not irrational denials of human uniqueness; they are a clear-sighted recognition of connection across the discredited breach of nature and culture" (p. 293). In Haraway's Staying with the Trouble, she offers a more encompassing notion of kinship: "My purpose is to make 'kin' mean something other/more than entities tied by ancestry or genealogy" (Haraway 2016, p. 103). Haraway further locates the idea of kinship as an "uncanny" bond between different "critters: "Kin is an assembling sort of word. All critters share a common 'flesh', laterally, semiotically, and genealogically. Ancestors turn out to be very interesting strangers; kin are unfamiliar (outside what we thought was family or gens) uncanny, haunting, active" (ibid., p. 103). Evoking "speculative feminism" (p. 2), Haraway comments on the science fictional mode's centrality to this notion of extended kinship: "sf [science fiction] is practice and process; it is becoming-with each other in surprising relays" (p. 3). Reading Faber's novel in light of Haraway's observation, we see how it becomes an exercise in "becoming-with each other" and "speculative feminism" but, unlike Haraway's celebration of boundary confusion, Faber's tale is much bleaker.

The metaphor of the animal/human/alien becomes in the novel a complex meditation on the nature of the 'human' as always already 'other'. The return to Nature in the lake scene quoted above becomes yet another irony in the novel. Isserley's wish to protect Nature and her search for kinship with the sheep further complicates her position as a hunter of 'vodsels' for the purposes of consumption. If the sheep look like "human children" (Faber 2001, p. 150), then Isserley's denial of 'vodsel' humanity is even more striking.

Sarah Dillon comments on the renaming gesture in the novel: "The renaming of what the reader understands to be human beings as 'vodsels,' like the transfer of the species name 'human beings' to Isserley's alien race, ... is a crucial textual method of destabilizing the reassuring divisions that we, the readers, as a species draw between ourselves and the animals we eat, experiment upon, or otherwise do 'justified' violence to" (Dillon 2011, p. 139). Isserley's failed attempt to communicate with her "fellow traveler", the sheep, demonstrates the ways language plays a central role in the novel: "Despite its bizarre features, there was something deceptively human about it, which tempted her, not for the first time, to reach across the species divide and communicate. 'Hello,' she said. 'Ahl,' she said. 'Wiin,' she said. These three greetings, which had no effect on the sheep except to make it scramble away, exhausted all the languages Isserley knew" (Faber 2001, p. 63). The language barrier exists then not only between 'humans' and 'aliens' but also between 'humans', 'aliens' and alien animals. 
As Hilderbrand rightly observes, "[t]he novel is narrated from a flatly omniscient perspective, and although the alien's routine does not initially make sense, everything is eventually explained to the reader." Unlike the novel, the film, as Hilderbrand notes, "operates through a formalist logic of disorientation: The narrative frustrates rather than offers intelligibility or character motivation" (Hilderbrand 2016).

This becomes even more evident by Glazer's use of minimalistic dialogue, becoming silence in the second part of the film after the alien's unexplained transformation. The thick, at times unintelligible, Scottish accent further frustrates understanding. Glazer does not provide subtitles and leaves this unintelligibility as an integral part of the viewers' experience, and, as Hilderbrand notes, perhaps also mirroring the alien's disorientation and communication breakdown: "Human communication seems essentially irrelevant to the alien and does little to offer exposition or give access to character interiority." The shifts between the documentary mode and the surrealist scenes of what seems to be an alien interiority thus "create a jarring cognitive dissonance that may resemble the alien's own disorientation. It does this, seemingly, in service of a film pondering what it means to be human. But it also works to structurally frustrate identification with the film's protagonist, repeatedly keeping her a seeming other, even when we are positioned to see her stare back in the mirror" (Hilderbrand 2016).

\section{The Monstrous Feminine: Fear of Female Alterity}

The notion of the female as an utterly alien being in the film, as I have suggested, is also related to the gendered dynamics the films presents. But although the female alien is the 'hunter', seducing males and leading them to a scene of disintegration in a 'feminine'/watery element, the patriarchal power structure remains intact in both film and novel. Male authority is at the heart of both works of art. In Glazer's film, the men on motorcycles who seem to be the ones in charge of the alien female offer a sinister example of mute authority which is never explained. We assume they too are aliens, but we are never given an explanation but only a visual image of the 'man-machine' bond emblematized in the motorcycle as coded symbol of speed and perhaps of male potency. The technological aliens, in line with the SF tradition to which Under the Skin belongs, are cold and efficient 'killing machines'. The motorcycle is a symbol of technological efficiency and the supremacy of the 'machine' over the 'human', and this familiar trope is employed in Glazer's film to visually suggest this notion of otherness while grounding it in a familiar image of the fast pace of city life. As in other instances in the film, the 'realistic' image meets the science-fictional imaginary and creates a coded symbol of alterity which is never fully explained.

Thus, male fear of female sexuality is literalized in the scenes of seduction and dissolution, but the ultimate power remains in male hands in both novel and film. The film relates this image to the male horror of the female "other". As Barbara Creed famously claims in The Monstrous Feminine, the fear of the "monstrous feminine" informs the depictions of female figures in literature and film from the archetypal Eve to current day depictions of female monstrosity. Creed offers the term "monstrous feminine" instead of a "female monster", which is simply the reverse of the male monster. Instead, Creed claims that "the reasons why the monstrous feminine horrifies her audience are quite different from the reasons why the male monster horrifies his audience. As with all other stereotypes of the feminine, from virgin to whore, she is defined in terms of her sexuality" (Creed 1993, p. 3). Thus, the term 'monstrous feminine' "emphasizes the importance of gender in the construction of her monstrosity" (ibid., p. 3). The dual function as mother/lover, nurturer/devourer finds expression in the disturbing images of the female as always already 'alien'. As David Roche claims in his reading of the Female alien in Under the Skin: "The Female conflates characteristics of various figures of what Barbra Creed (1993) calls the 'monstrous-feminine': like Medusa, her gaze is deadly; like the vagina dentata, she murders most of her victims by incorporation; like the vampire, she seduces her victims whose life is sucked out of them; and like the witch, she casts a spell on her victims and leads them into her cauldron before she is ultimately burned alive by the Logger" (Roche 2017, p. 49). 
Glazer opts for a depiction of radical otherness with no psychological or cultural explanations to account for the main character's actions. We see the transformation in the 'emotional' reactions of the female but are given no clue as to why that shift occurs. We see the female interact with the deformed man she meets and later sets free. Is this encounter a turning point? Why does the female set him free after capturing him? What is the reason for her escape after this scene? What is the nature of her relationship with the 'Kind Man' who takes her into his home and seemingly also into his heart? What is the meaning of the love-making scene and why does the female flee after what seems to be an unsuccessful consummation of the sexual act? What does the female see when she looks at her own genitals (or lack thereof) in the mirror after the failed sexual act? Who are the men on motorcycles who seem to be the ones in charge? We are never given any clear answers. As Landin notes,

One of the challenges was to capture her gaze, which is devoid of subjectivity because she has none. At the beginning of the film, she doesn't have any emotional connection to the landscape or her human body, and she doesn't react to beauty or violence, and we wanted our cameras to convey that objectivity. Then, as the film progresses, human emotion starts to corrupt her vision, and also ours. She starts to learn how to see more like a human, a condition which can only lead to her demise. (Stasukevich 2014, p. 45)

\section{Food for Thought: Reading Under the Skin}

Glazer's depiction of the inscrutable female figure suggests we 'read' the enigma in visual terms. Under the Skin is almost a 'silent film'; the viewers need to rely on the visual; they will 'see' with the female's eyes and finally with her would-be rapist's eyes, when what is 'under the skin' is revealed. Faber's novel ends with Isserley's choice to commit suicide and mingle with the 'elements' whereas Glazer's film ends with the immolation of the female alien by the horrified male rapist and with an upward shot of snow falling down on the smoldering heap.

To what extent do these brutal endings amount to a denial of the very idea of female power in a male world? I would suggest that the dialogue between the novel and the loose filmic adaptation renders alien what we have come to see as the 'norm'. The science fictional allegory, in both film and novel, destabilizes our notions of self and other. While Faber provides the readers with an inside look into an 'alien' consciousness that is a mirror of our own societal norms regarding animals and women as 'meat', Glazer's film opens with an enigmatic scene of possible 'rebirth' into symbolic language. As Thomas Puhr claims, "Under the Skin begins with a rebirth of sorts, when an extraterrestrial assumes the outward appearance of a human seductress. Though this physical transformation is never explicitly revealed or explained, Glazer implies the character's assumption of a new identity by showing 'her' donning human clothes, applying make-up and practicing the English language" (Puhr 2017, p. 29).

We see an optic device which finally becomes a human eye, perhaps echoing the famous computer "eye" in Kubrick's 1968 canonical 2001: A Space Odyssey, and placing Glazer's film in the tradition of SF [science fiction] films about alterity and the limits of humanity. As David Roche notes, "the opening credits inscribe the film within the $[\mathrm{SF}]$ genre, notably by referring to the motif of the eye present in 2001: A Space Odyssey" (Roche 2017, p. 48). This image is accompanied by strange 'alien' sounds, again perhaps echoing Kubrick's score, and we hear a female voice making sounds which become words in English.

This seems to suggest that the female we later see has to acquire (human) language in order to perform in the human world. But the film limits her dialogue with others to the most basic interaction needed to lure the men into her van. In the second half of the film, after she sets the deformed man free, she becomes silent. Her role as predator is over and with it the need for human language as a tool to catch her prey.

After this seeming change in the female's behavior, we see her stumble out on her own in what would appear to be a different exploration of the human world, not merely as a killing ground, or source of food. However, the film ingeniously plays with the notion of consumption by placing the female in a scene where she tries to consume human food and fails. 
In this semi-comic moment in the film, the alien female tries to eat a piece of cake. She stumbles into a roadside café and attempts to be 'human' by ordering a large piece of chocolate cake. She gingerly brings the fork to her mouth and tries to eat, but cannot and throws up the 'offending' food while everyone stares at her. This scene is left unexplained. Why does she try to eat human food? Is this an attempt to 'become' human? She throws up the offending food, not being able to digest it, thus perhaps hinting at the many ways the threat of food figures in the lives of most women. In a similar manner, her experiences as a sexual being are a coded comment on the ways women are perceived as mere bodies, sexual objects to be looked at and used.

As Piatti-Farnell notes in Consuming Gothic, the horror genre is replete with images of food and consumption. The role of food in the horror imaginary is complex as the very idea of eating involves a confusion of inside/outside, and a blurring of bodily limits: "[T] here is a certain unavoidable Otherness about the very process of eating" (Piatti-Farnell 2017, p. 4). Piatti-Farnell relates to the idea of consumption as a horror trope: "Food is a liminal subject, one that breaks the seemingly fixed boundaries of the body, society and culture" (ibid., p. 4). Furthermore, "food continues to be intertwined with frameworks of desire, that in turn affect our understanding of constraint, excess and depravation" (p. 11).

Faber's novel makes the connection between consumption and female alterity more explicit. Isserley is reminded of her troubled attempts with 'vodsel' food: "[S]he peered longingly at the snacks displayed in the sickly fluorescent light. There was nothing fit for human consumption, as far as she could tell. And yet, there surely must be. It was just a matter of making the correct choice ... The last time she had been adventurous and eaten something meant for vodsels she had ended up in bed for three days" (Faber 2001, p. 130). When Isserley is tempted to eat 'vodsel' meat, however, she becomes "dizzy with desire" (p. 162). It is only when Amlis Vess, the boss's son who comes to visit the farm, tells her that the meat she is eating is "the body of a creature that lived and breathed just like you and me" (pp. 162-63) that Isserley feels "a tiny thread of meat lodged in her throat" (p. 164); this "tiny" disruption is the beginning of Isserley's awareness of 'vodsel' humanity. Glazer's short scene seems to gesture back at the novel's engagement with the conflicted relationship between women, consumption, and the fear of ingestion. Viewing humans/animals as 'meat' to be consumed is a major trope in both the novel and the film. The seduction scenes in Glazer's film are connected to the fear of consumption in the cake scene discussed above as well as to the idea of 'women' as 'meat' to be consumed by men, and the film and novel's inversion of this gendered dynamics.

\section{Bodies without Organs: Rethinking Desire and the Human Condition}

The idea of consumption in its many forms is central to both the film and the novel, as I have suggested. I turn then to possible exploration of the ambiguous scenes of bodily dissolution in Glazer's film via a cultural trope which manifests the idea of the personal and cultural body as a 'body without organs' (shortened in the text to $(\mathrm{BwO})$. Using Deleuze and Guattari's famous formulation, I wish to locate the ways in which the 'body' figures in the film and what we can deduce about Glazer's allegory by relating to this notion: the film offers us a striking visual image of the horror inherent in the idea of the body as a mere container, which can be emptied out and consumed. In Deleuze and Guattari's terms, the human condition strives towards this emptying out of the body: "You never reach the Body without Organs, you can't reach it, you are forever attaining it, it is a limit .... On it we sleep, live our waking lives, fight-fight and are fought—seek our place, experience untold happiness and fabulous defeats; on it we penetrate and are penetrated; on it we love" (Deleuze and Guattari 1987, p. 150). Providing a catalogue of 'bodies without organs' (the hypochondriac body, the schizo body, the paranoid body, the drugged body) as emblems of psycho-cultural ailments, Deleuze and Guattari question the other aspect of this bodily denial, or pathology: "Why such a dreary parade of sucked-dry, catatonicized, vitrified, sewn-up bodies, when the BwO is also full of gaiety, ecstasy, and dance?" (p. 150). The figure of the BwO can also be 'positive'. The conflicted relations with the human body can be a site of experimentation: “Where psychoanalysis says, 'Stop, find your self again,' we should say instead, 
'Let's go further still, we haven't found our BwO yet, we haven't sufficiently dismantled our self.'” (p. 151). The $\mathrm{BwO}$ is linked to sexual imagination and desire; "The $\mathrm{BwO}$ is the field of immanence of desire, the plane of consistency specific to desire (with desire defined as a process of production without reference to any exterior agency, whether it be a lack that hollows it out or a pleasure that fills it)." (p. 154). As Ian Buchanan elucidates, the body without organs "is produced by the process of desire, but it also has an effect on desire" (Buchanan 2014, p. 256). Under the Skin plays out this dynamic of desire and lack. The female's immolation at the end of Glazer's film is preceded by the divestment of the (alien) body of its (human) skin. The scene shows the female 'peel' off her skin, 'shedding' it like a snake, to reveal the black 'skin' underneath.

If we return to the question of alien 'nature' which both Glazer's film and Faber's novel pose, we can see that Glazer's visual metaphors reinforce the inability of ever truly knowing the 'alien'. The very idea of the 'alien' can only be understood in metaphorical terms. Ian Bogost's Alien Phenomenology displaces the human as the center of inquiry, claiming that "when objects that are alien to each other encounter each other, they can only make sense of each other through metaphor (Bogost 2012, pp. 66-67)." According to Bogost, the alien is "difference itself and suggests our fundamental inability to understand difference." (Bogost 2012, p. 34) As Bogost elucidates, "It's not just that the communications technologies of the alien escape our comprehension, but that their very idea of 'life' might not correspond with ours. But the alien is not limited to another person, or even another creature. The alien is anything —and everything-to everything else." (p. 34).

Glazer's film plays out this essential inscrutability of the alien as that which exceeds our comprehension. Even if we choose to read the film as an allegory of male-female relations, the film still remains an open-ended visual depiction of otherness qua otherness. The very idea of 'difference' is at the heart of the film, and its embodiment in the figure of the American film star, Scarlett Johansson, who became known for portraying 'alien' figures in films like Her, Lucy, and Ghost in the Shell may be an ironic gesture on Glazer's part. As Puhr notes, "The alien actually is a model that is enclosed in the 'mysterious appearance' of a human body (just as the actor is 'enclosed' in his/her role)." (Puhr 2017, p. 32). The well-known star dons a black wig and picks up men in the 'alien' Scottish landscape, thus showing how 'national' alienness is tied to the science-fictional trope and to the hyper-sexualized presentation of the 'star' as 'other': not exactly 'human', but somehow exceeding humanity's limitations. When one of the men she picks up marvels at her beauty, she asks him in a coy manner: "Do you think I'm pretty?" to which he admiringly replies: "You're gorgeous!" duplicating the audience's reactions.

This comic moment highlights the paradoxical nature of Glazer's filmic project. By choosing a very well-known movie star and giving her the role of the ultimate alien, while playing with the documentary mode as a way of further enhancing this paradox, Glazer's film becomes a comment on alterity on many levels. The science fictional dimension is central, but it is by no means the only way to read the film. As I have suggested in this paper, the presentation of the body as a Gothic site, its porous boundaries broken down, 'peeled' to reveal an ultimate form of alterity, and finally immolated, signal the ways in which the 'human' is a very unstable category. Glazer uses the Gothic trope of a 'home' as the locale of unfathomable horror, and links the notions of 'body', 'home' and the fear of being consumed, into a symbolic scene of the meeting between desire, consumption and death. The film's power lies in its ability to present audiences with the uncanny site of bodily disintegration, while questioning whether we can ever understand the 'other': 'human', 'alien', 'animal', or 'woman'. All remain inscrutable figures of difference, which are also mirrors of our own alienation. When we see the beautiful, naked Johansson stare at herself in the mirror after her meeting with the kind man who seems to understand her, although they never communicate verbally, we are left to ponder what 'she' sees and how 'we', as an audience, are meant to read this 'naked' (in both senses of the word) moment of poignant observation of the female body. As we see the 'movie star' playing the role of an alien female, our preconceived notions of stardom are also questioned. What does this view of the 'star' as an 'alien' mean? How is the actress implicated in the role she plays? What makes her the perfect alien 
figure? Our view of the well-known 'star' as a vulnerable being, subject to our gaze, but also defying it by her inscrutable nature as a figure of ultimate difference, becomes a marker for the ultimate alterity that Glazer's film portrays in such a convincing manner.

The horrific ending of the film is seemingly 'softened' by the blanket of snow falling down and dousing the flames of the alien female's burning body. Glazer here gestures back to the novel's ending when Isserley reflects on her 'afterlife': "Her invisible remains would combine, over time, with all the wonders under the sun. When it snowed, she would be part of it, falling softly to earth" (Faber 2001, p. 296). Both novel and film end with the annihilation of the 'body'. But both leave the reader/viewer with the possibility of an afterlife, a way of merging with 'Nature'. As Puhr notes, "The final scenes, which culminate in its (the alien's) violent death, are saturated with rain and snow. The last shot, as a matter of fact, is an upward angle of a snowing sky; as the snowflakes accumulate on the camera lens, the viewer feels as if (s)he too is being buried under the snow, beside the alien's smouldering remains" (Puhr 2017, pp. 29-30). The novel ends with Isserley's thought that "she would live forever" (Faber 2001, p. 297), and with her final words "here I come" (p. 297), ending the novel on an almost exalted note. Her suffering seems to be over, and her death a welcome release. But we are also left with the memory of the 'mirror scenes' in the film which perhaps show us how alienation in its most pervasive sense is always with us; when we look at our bodies in the mirror, when we 'see' ourselves, and when we attempt to the 'see' the 'other'. In this sense, the novel and the film may also become 'mirror images' of one another, each exploring in different artistic mediums, the very idea of humanity as always-already 'other'. Ultimately, and this may be what Glazer's film is trying to show us, we are all alien(ated), and face an incomprehensible world trying to read its unintelligible signs but failing more often than not.

Funding: This research received no external funding.

Conflicts of Interest: The author declares no conflict of interests.

\section{References}

Bogost, Ian. 2012. Alien Phenomenology, or What It's Like to Be a Thing. Minneapolis: University of Minnesota Press. Buchanan, Ian. 2014. Body without Organs. In Understanding Deleuze, Understanding Modernism. Edited by Paul Ardoin, Stanley E. Gontarski and Laci Mattis. New York: Bloomsbury, pp. 255-57.

Creed, Barbara. 1993. The Monstrous Feminine: Film, Feminism, Psychoanalysis. New York: Routledge.

Deleuze, Gilles, and Felix Guattari. 1987. A Thousand Plateaus: Capitalism and Schizophrenia. Translated by Brian Massumi. Minneapolis: University of Minnesota Press. Available online: http://www.lab404.com/420/ deleuze_guattari.pdf (accessed on 4 November 2018).

Dillon, Sarah. 2011. 'It's a Question of Words, Therefore': Becoming Animal in Michael Faber's Under the Skin. Science Fiction Studies 38: 134-54. [CrossRef]

Faber, Michael. 2001. Under the Skin. London: Cannogate Books.

Foucault, Michel. 1984. Of Other Spaces: Utopias and Heterotopias. In Architecture/Mouvement/Continuité. Translated by Jay Miskowiec. Des Espace Autres. March 1967. Available online: http://web.mit.edu/allanmc/ www/foucault1.pdf (accessed on 11 August 2019).

Haraway, Donna. 2000. A Cyborg Manifesto: Science, technology and socialist feminism in the late twentieth century. In The Cybercultures Reader. Edited by David Bell and Barbara M. Kennedy. London: Routledge, pp. 291-324. First published 1991.

Haraway, Donna. 2016. Staying with the Trouble: Making Kin in the Chthulucene. Durham and London: Duke University Press.

Hilderbrand, Lucas. 2016. On the Matter of Blackness in 'Under the Skin', Notes. Jump Cut: A Review of Contemporary Media. no. 57. Available online: http://search.ebscohost.com.rproxy.tau.ac.il/login.aspx?direct= true $\& \mathrm{db}=\mathrm{f} 3 \mathrm{~h} \& \mathrm{AN}=120827586 \&$ site $=$ ehost-live (accessed on 4 November 2018).

Kristeva, Julia. 1982. The Powers of Horror: An Essay on Abjection. Translated by Leon S. Roudiez. New York: Columbia University Press.

Piatti-Farnell, Lorna. 2017. Consuming Gothic: Food and Horror in Film. London: Palgrave McMillan. 
Puhr, Thomas. 2017. 'Mysterious Appearances' in Jonathan Glazer's Identity Trilogy. Film International 15: 28-33. [CrossRef]

Roche, David. 2017. Fault Lines in Under the Skin: An ethics and aesthetics of the 'monstrous'. Horror Studies 8: 45-59. [CrossRef]

Stasukevich, Iain. 2014. Alien Ways. American Cinematographer 95: 44-53. 